\title{
Oxytetracycline on functions and structure of soil microbial community
}

\author{
W. Chen ${ }^{1 *}$, W. Liu ${ }^{1}$, N. Pan ${ }^{2}$, W. Jiao ${ }^{1}$, and M. Wang ${ }^{1}$ \\ ${ }^{I}$ State Key Laboratory of Urban and Regional Ecology, Research Centre for Eco-environmental Sciences, Chinese Academy of \\ Sciences, Beijing, 100085, China. 'Department of Resources and Environmental Sciences, Shihezi University, Shihezi, Xinjiang, \\ 832003, China.*Corresponding author.e-mail: wpchen@rcees.ac.cn
}

\begin{abstract}
Effects of oxytetracycline (OTC) on soil enzyme activity and structural diversity of soil microbial communities were investigated. The low and moderate OTC inputs of less than $15 \mathrm{mg} / \mathrm{kg}$ enhanced microbial growth and increased the total and bacterial and fungal biomasses in the receiving soils. The antibiotic toxicity of OTC although targeted the bacteria in the soils proportionally resulted in greater harmed against the soil fungi than the bacteria and the Gramnegative bacteria fared significantly better than the Gram-positive bacteria. Collectively, the high OTC inputs lowered of soil enzymatic activities and the low and moderate OTC inputs did not have any adverse impact on the soil enzyme activities.
\end{abstract}

Keywords: Veterinary antibiotic, soil enzyme activity, PLFAs, soil microbial mass

\section{Introduction}

Veterinary antibiotics are widely used as growth promoters and for therapies of infectious diseases in livestock farming. Worldwide, about 100,000 to 200,000 tons of antibiotics are used annually (Jeong et al., 2010) with 30 to $90 \%$ of the parent compounds find their ways into the environment (Halling-Sorensen et al., 1998; Sarmah et al., 2006). The antibiotics may reach the soil through livestock excreting on pastures or the use of manures as fertilizers. Accumulation of antibiotics in soils poses potential threats to the functions and structure of microbial communities in receiving soils (Demoling et al., 2009; Johnsen et al., 2011; Kong et al., 2006; Liu et al., 2009; Liu et al., 2012).
Oxy-tetracyclines (OTCs), the most common veterinary antibiotics, possess broad-spectrums of antimicrobial properties including block the transfer of RNA and prevent synthesis of proteins. OTCs are poorly adsorbed or metabolized by the targeted livestock animals; resulting in large amounts being inadvertently released to the environment through excretions of feces and urine (Tolls, 2001). They are found in receiving soils at the parts per million concentration levels due to repeated applications of manures, occasionally exceeding the $100 \mathrm{ppm}$ level (Zhou et al., 2011). Consequently, the activities and function of the soil microbial community are adversely 
affected (Boleas et al., 2005; Kong et al., 2006; Liu et al., 2009; Thiele-Bruhn and Beck, 2005) and the soil microbes develop pollution-induced tolerant and antibiotic resistant genes (Brandt et al., 2010; Schmitt et al., 2006; Zhu et al., 2010).

The fates of OTCs in soil are related to not only the inherent soil properties of organic matter, $\mathrm{pH}$, solid/ solution ratio, and cation speciation (Tolls, 2001; Zhou et al., 2010), but also the nature of aboveground vegetation (Migliore et al., 2010; Yang et al., 2009). Antibiotics, including oxy-tetracyclines, tetracycline, sulfadiazine, sulfamethoxazole, and ciprofloxacin harmed the function and structure of the soil microbial community and reduce the soil enzymatic activities (Demoling et al., 2009; Ding and He, 2010; Kotzerke et al., 2011). Do soil enzyme activities change in proportion to amounts of antibiotics present? What is the role of aboveground vegetation on the soil microbial activity of an OTC-stressed community? We hypothesized that the vegetation would dampen the antibiotics' adverse impacts on activities and functions of soil microbial community.

In this research, greenhouse experiments growing two types of plants in soils receiving three levels of OTC inputs were conducted to assess effects of OTC concentrations and vegetation patterns on changes of soil microbial (1) functions assessing activities of 4 enzymes involved in $\mathrm{C}, \mathrm{N}, \mathrm{P}$, and $\mathrm{S}$, cyclings, respectively and (2) community structure analyzing the phospholipid fatty acids (PLFAs) profiles.

\section{Material and Methods}

\subsection{Antibiotics incorporation}

Surface horizon $(0$ to $20 \mathrm{~cm})$ of the soils at an agricultural experiment station farm near Beijing was collected during the autumn, 2011 for the experiments. In the immediate past five years, the land where soils were obtained was in annual corn productions. The soil was a loam with $\mathrm{pH}$ of 8.3 , and the organic matter, clay, silt, and sand contents of 1.2, 9.2, 38.6, and $52.2 \%$, respectively. The soil was air-dried and sieved to pass a screen with $2 \mathrm{~mm} \times 2 \mathrm{~mm}$ openings. The manure was collected from a local swine farm with no history of feeding antibiotics. It was air-dried, sieved to pass a screen with $2 \mathrm{~mm} \times 2 \mathrm{~mm}$ openings and stored at room temperature until use.

Two hundred seventy grams (270 g dry weight) of swine manure were mixed with OTCs to reach three concentration levels and then blended into $9 \mathrm{~kg}$ soil, resulting in a typical manure application of $30 \mathrm{mg} / \mathrm{g}$ soil. The final OTC concentration in spiked soil was $1,15,200 \mathrm{mg}$ OTCs $/ \mathrm{kg}$ of soil, respectively. The soil OTC concentrations up to $1 \mathrm{mg} / \mathrm{kg}$ were typical in ordinary agricultural operations, while those of 119 to $307 \mathrm{mg} / \mathrm{kg}$ had been observed in soils irrigated with domestic wastewater (Zhou et al., 2011). The three soil OTC concentrations were selected to bracket levels observed in the fields.

Fertilizers including urea, $\mathrm{KH}_{2} \mathrm{PO}_{4}$ and $\mathrm{K}_{2} \mathrm{SO}_{4}$ were added to soil at $0.15 \mathrm{~g} \mathrm{~N} / \mathrm{kg}, 0.12 \mathrm{~g} \mathrm{P} / \mathrm{kg}$, and $0.15 \mathrm{~g} \mathrm{~K} /$ $\mathrm{kg}$, respectively. Soil moisture content was adjusted to 50 to $60 \%$ of maximum water holding capacity using distilled water. The OTC-spiked soils were then divided evenly and packed into 9 PVC plant growing pots, $15 \mathrm{~cm}$ in height and $10 \mathrm{~cm}$ in diameter, covered, and incubated in darkness at room temperature for 6 days.

\subsection{Experimental design}

A two-factor $(\mathrm{P} \times \mathrm{A})$ randomized block design with three replications was used, in which factor "P" denoted plant species including 3 levels of P0: no vegetation, $\mathrm{P} 1$ : red amaranth (Amarantus mangestnus L.), and P2: white clover (Trifolium repens L.) and factor "A" denoted OTC concentration of soils including 4 levels A0: $0 \mathrm{mg} / \mathrm{kg}, \mathrm{A} 1: 1 \mathrm{mg} / \mathrm{kg}, \mathrm{A} 2$ : $15 \mathrm{mg} / \mathrm{kg}$, and A3: $200 \mathrm{mg} / \mathrm{kg}$ ). Red amaranth was chosen to represent a plant with short growing period and widespread cultivation in northern China. The 
cultivation in northern China. The white clover was selected for its wide applications in pastures and forage productions and its special rhizosphere microorganisms. After the initial incubation, pots for the plant treatment were sown with either 15 red amaranth seeds or 20 white clover seeds each. Seven days after germination, plants were thinned to 6 and 15 plants for red amaranth and white clover, respectively. Soil moisture content was maintained at 50 and $70 \%$ of the maximum water holding capacity at early and middle-late stages, respectively. The experiment was carried out in a glasshouse maintained at 20 to 27 and 15 to $20^{\circ} \mathrm{C}$ day and night temperature ranges, respectively. The plant growing experiment lasted 7 weeks.

\subsection{Phospholipid fatty acids and soil enzymatic activities assays}

Microbial biomass and community composition were assessed by the PLFAs. After plants were harvested, the soil at field conditions was crushed, mixed, and sieved to remove visible plant roots, freeze-dried at $-45^{\circ} \mathrm{C}$, and then passed through a $0.15 \mathrm{~mm}$ mesh sieve. All solvents and reagent chemicals for the extractions were either analytical or chromatographic grade. The total phospholipids were extracted from $3 \mathrm{~g}$ freezedried soil aliquots with a chloroform-methanolcitrate mixture buffer at the 1:2:0.8 volumetric ratios, followed by vortex mixing, shaking and centrifuging and then fractionated into glycolipids, neutral lipids, and polar lipids. The lipid extracts in chloroform phase were transferred to silica-filled solid phase extraction (SPE) columns. Phospholipids were separated from neutral lipids and glycolipids by subsequently eluting with chloroform, acetone and methanol, respectively. Then, the phospholipids in the methanol fraction were hydrolyzed and methylated using a mixed solution of $\mathrm{KOH}$ and methanol. Hexane-chloroform mixture was added for repeating extraction process. An internal standard, c19:0 (methylene nonadecanoate) was added to quantify the PLFAs. The PLFAs were separated by an Agilent $6890 \mathrm{~N}$ gas chromatograph, equipped with a HP-5 column $(25.0 \mathrm{~m} \times 0.33 \mathrm{~mm}$ $\times 200 \mu \mathrm{m})$ and identified by a MIDI Sherlock microbial identification system. Nitrogen was used as carrier gas with a flow rate of $0.8 \mathrm{ml} / \mathrm{min}$. The oven temperature started at $170{ }^{\circ} \mathrm{C}$ for $1 \mathrm{~min}$, ramped to $260{ }^{\circ} \mathrm{C}$ at $5{ }^{\circ} \mathrm{C} / \mathrm{min}$, and increased to $310^{\circ} \mathrm{C}$ at $40{ }^{\circ} \mathrm{C}$ $/ \mathrm{min}$, and retained for $1.5 \mathrm{~min}$.

According to the fatty acid nomenclature described by Frostegard et al. (1993), the branched phospholipids i15:0, a15:0, i16:0, i17:0, and a17:0 were used as indicators for Gram-positive bacteria

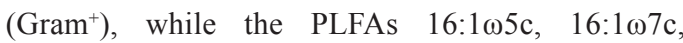
$17: 1 \omega 8 \mathrm{c}$, cy17:0, and cy19:0 were considered as Gram-negative bacteria $\left(\mathrm{Gram}^{-}\right)$. The unsaturated

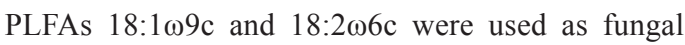
biomass indicators, while 15:0 and 17:0 PLFAs were considered as general bacteria markers. The ratios of $\mathrm{Gram}^{-} / \mathrm{Gram}^{+}$PLFAs and bacterial/fungal PLFAs were used for elucidating the changes in microbial community. The stress level (cyc/precursor) for the microbial community was calculated according to the ratio of $(\operatorname{cyc} 17: 0+\operatorname{cyc} 19: 0) /(16: 1 \omega 7 \mathrm{c}+18: 1 \omega 7 \mathrm{c})$ (Frostegard et al., 1993; Hammesfahr et al., 2008). The activities of urease, dehydrogenase (DH), alkaline phosphatase (ALP), and arylsulphatase (ARS) were assayed according to the methods described by Guan (1983). The urease activity was measured in citrate buffer solution $(\mathrm{pH}$ 6.7) using sodium phenolate substrate. The dehydrogenase was measured in Tris-HCl buffer solution $(\mathrm{pH} 7.6)$ using 2,3,5-triphenyltetrazolium chloride substrate. The alkaline phosphatase was measured in citrate buffer solution (pH 7.0) with 2,6-dibromo-N-chlorop-benzoquinoneimide substrate. The aryl sulphatase was measured in sodium acetate buffer solution $(\mathrm{pH}$ 5.8) with 4-nitrophenyl sulfate substrate.

\subsection{Data analysis}

Data were subject to analysis of variance and significant difference between means were separated by using Duncan's new multiple range tests at the $5 \%$ level using SPSS 18.0. 
A
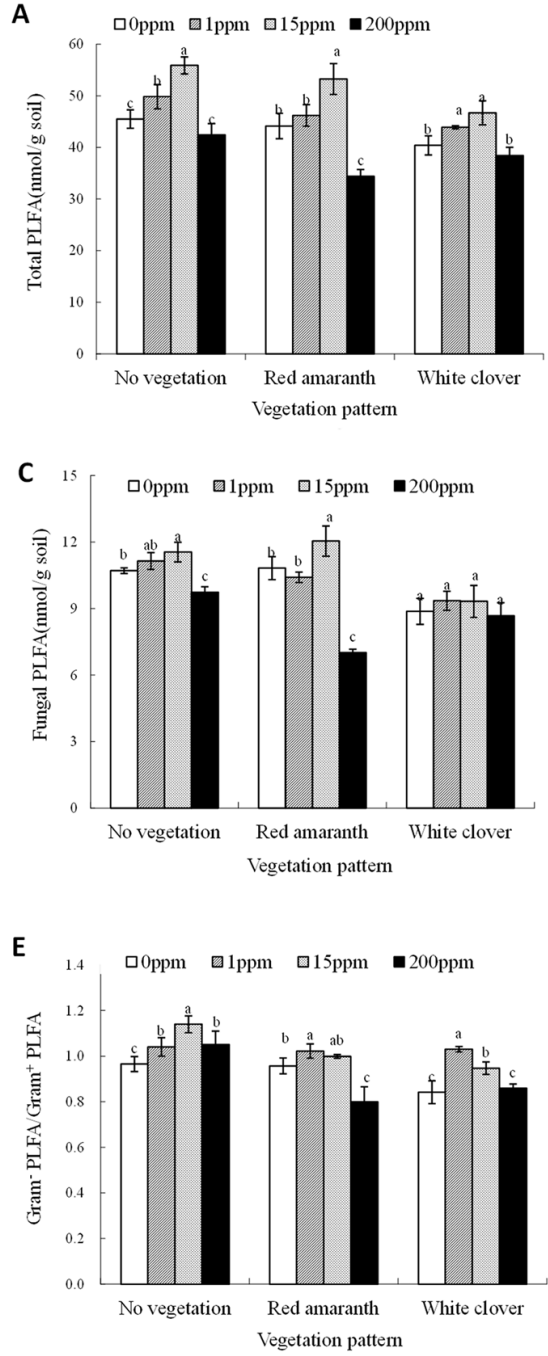

B
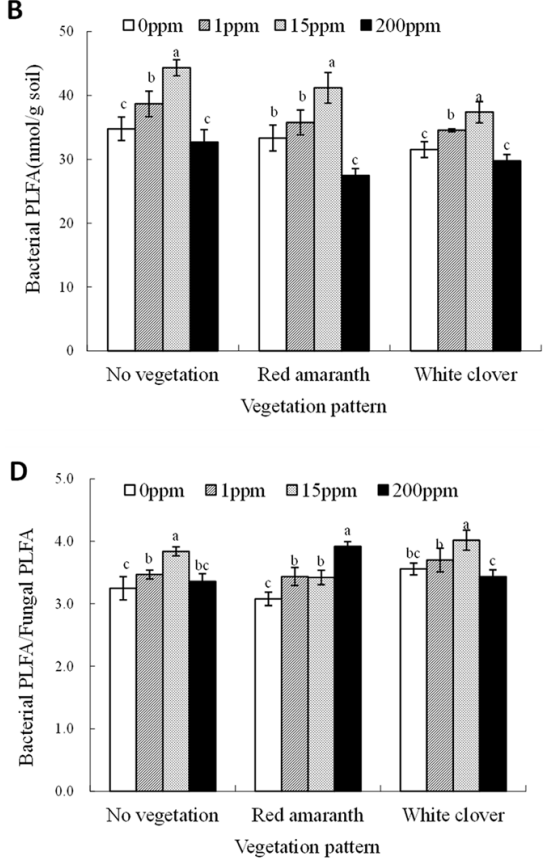

$\mathbf{F}$

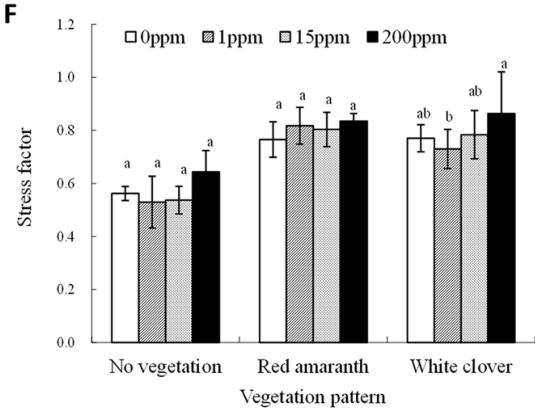

Figure 1. Phospholipid fatty acids (PLFAs) of soils seven weeks after receiving $0,1,15$ and $200 \mathrm{mg} / \mathrm{kg}$ of oxytetracycling under the types of vegetative covers. Each bar and its range bracket denote the arithmetic means \pm standard deviation $(\mathrm{n}=3)$ of the indicated parameter and experimental condition. Different letters within each group of bars indicate values are significantly different at $p<0.05$ according to ANOVA. 


\section{Results}

\subsection{Microbial biomass and community structure}

The total PLFAs of planted soils increased under the low and medium OTC inputs of 1 and $15 \mathrm{mg} / \mathrm{kg}$ and significantly decreased at $200 \mathrm{mg} / \mathrm{kg}$ OTC treatment comparing to those of the no antibiotic experimental control (Figure 1). The total PLFAs of the soils followed the descending order of $15 \mathrm{mg} / \mathrm{kg}>1 \mathrm{mg} /$ $\mathrm{kg}>$ no antibiotics experimental control $>200 \mathrm{mg} / \mathrm{kg}$. The trend was consistent across the board for all three plant treatments. For the no plant experimental control, those at $15 \mathrm{mg} / \mathrm{kg}$ of OTC treatment were $22.8,12.1$, and $31.6 \%$ higher than those at 0,1 and $200 \mathrm{mg} / \mathrm{kg}$ OTC treatment, respectively. For soils planted with red amaranth, the total PLFAs at $15 \mathrm{mg} / \mathrm{kg}$ OTC treatment were $20.6,15.3$, and $54.9 \%$ higher than those at 0,1 and $200 \mathrm{mg} / \mathrm{kg}$ OTC treatments, respectively. For soils treated with white clover, the total PLFAs at $15 \mathrm{mg} / \mathrm{kg}$ of OTC treatment were 15.6, 6.4, and $21.5 \%$ higher than those at 0,1 and $200 \mathrm{mg} / \mathrm{kg}$ OTC treatments, respectively. The total PLFAs of soils planted with red amaranth sustained the greatest extent of harms when OTC treatment was at the $200 \mathrm{mg} / \mathrm{kg}$.

Similarly, the bacterial PLFAs of the planted soils responded to the antibiotic treatments in descending order of $15 \mathrm{mg} / \mathrm{kg}>1 \mathrm{mg} / \mathrm{kg}>$ no antibiotics experimental control $>200 \mathrm{mg} / \mathrm{kg}$ (Figure 1B). At the $15 \mathrm{mg} / \mathrm{kg}$ OTC treatment, the bacterial PLFAs of soils were 18.6 to $27.5 \%$ higher, and at the $200 \mathrm{mg} / \mathrm{kg}$ OTC treatment, the bacterial PLFAs were significantly reduced regardless of aboveground covers. Cross the board, the bacterial PLFAs were approximately 3.5 times more than those of the fungal PFLAs. However, the fungal PLFAs of plant treated soils responded to the soil borne antibiotics in different manners (Figure 1C). For soils of the no plant experimental control and red amaranth treatment, the amounts of fungal PLFAs in soils containing $200 \mathrm{mg} / \mathrm{kg}$ were significantly lower than those containing 0,1 and 15 $\mathrm{mg} / \mathrm{kg}$ OTC, while the fungal PLFAs of soils treated with white clover were not significantly different across the 0 to $200 \mathrm{mg} / \mathrm{kg}$ OTC treatments. The fungal PLFAs of soils planted with red amaranth decreased by $41.8 \%$ from $12.0 \mathrm{nmol}$ PLFAs $\mathrm{g}^{-1}$ soil at the $15 \mathrm{mg} / \mathrm{kg}$ OTC treatment to $7.0 \mathrm{nmol}$ PLFAs g ${ }^{-1}$ soil at the $200 \mathrm{mg} /$ $\mathrm{kg}$ OTC treatment.

The aboveground plant species had significant influences on the bacteria vs. fungi and bacteria vs. bacteria distributions in the OTC antibiotic treated soils and the outcomes appeared to be soil OTC concentration-dependent. Compared to the no OTC treatment, adding OTC to the soils, with the exception of $200 \mathrm{mg} . \mathrm{kg}$ OTC treated soils of white clover, increased the soil's bacterial/fungal PLFAs ratios (Figure 1D). The ratios of Gram $\%$ $\mathrm{Gram}^{+}$bacterial PLFAs in soils of 1 and $15 \mathrm{mg} / \mathrm{kg}$ OTC treatments were significantly higher while the ratio of $\mathrm{Gram}^{-} / \mathrm{Gram}^{+}$bacterial PLFAs of the 200 $\mathrm{mg} / \mathrm{kg}$ OTC treatment was significantly lower than that of the $0 \mathrm{mg} / \mathrm{kg}$ OTC level experimental control (Figure 1E).

The stress factors for the soils remained unchanging across the OTC treatments (Figure 1F). The stress factors of soils receiving antibiotic treatments were not significantly different if the soils were not planted and were treated with $1 \mathrm{mg} / \mathrm{kg}$ of OTC. The exception was the stress factor of soils planted with white clover when the soil OTC was at the $200 \mathrm{mg} / \mathrm{kg}$.

\subsection{Soil enzyme activities}

The antibiotics OTC adversely affected the enzyme activities in the receiving soils including those of dehydrogenase, urease, alkaline phosphatase, and arylsurfatase (Figure 2). The dehydrogenase arylsulfatse activities of the soils with no vegetation and red amaranth decreased significantly along the OTC concentration gradient of $0,1,15$, and 200 $\mathrm{mg} / \mathrm{kg}$ (Figure 2A and 2D) and the dehydrogenase and arylsurfatase activities of white clover were not significantly different along the same OTC concentration gradient. The aboveground plants affected the outcomes. 

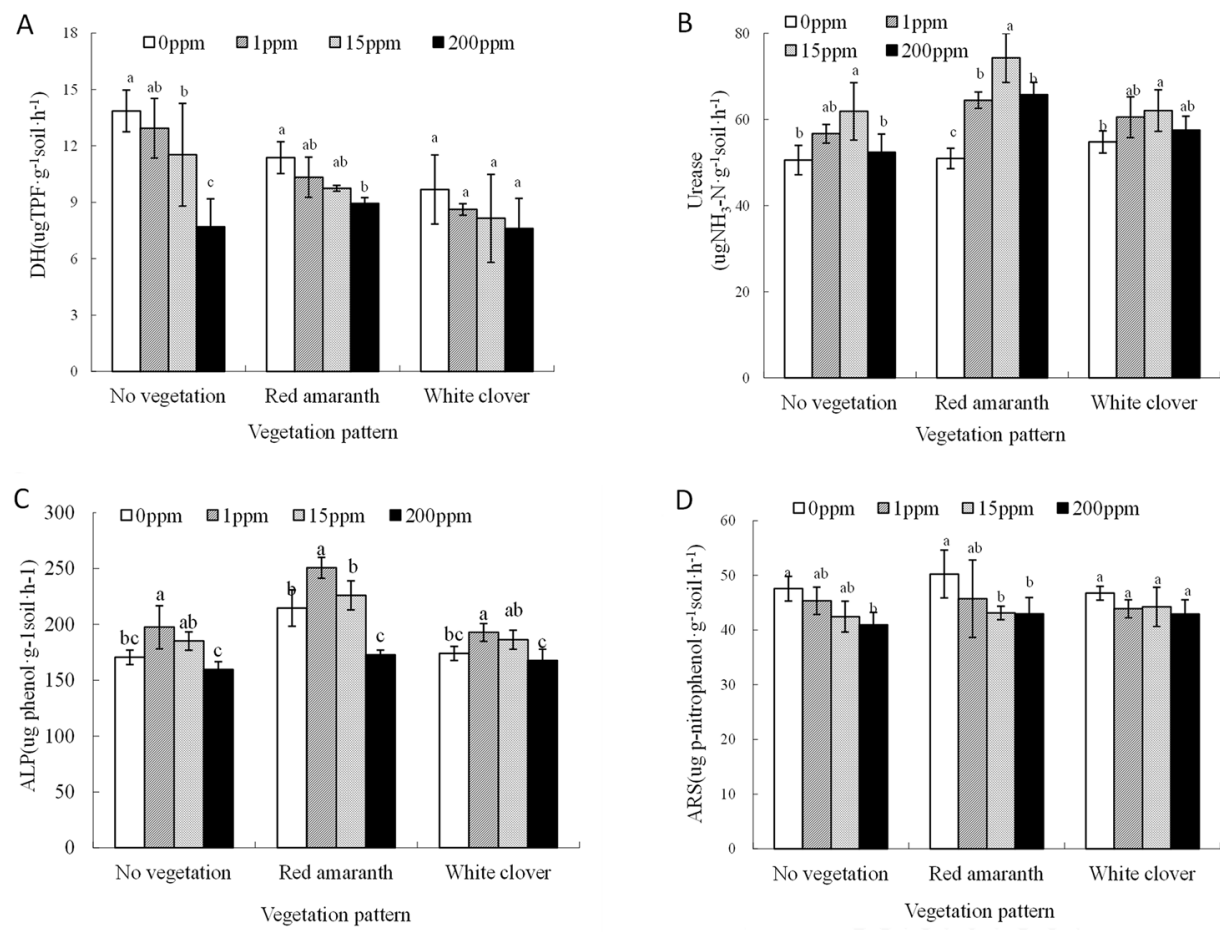

Figure 2. The activities of dehydrogenase (DH), urease, alkaline phosphatase (ALP), and arylsulphatase (ARS) of soils seven weeks after receiving $0,1,15$ and $200 \mathrm{mg} / \mathrm{kg}$ of oxy-tetracycling under three types of vegetative covers. Each bar and its range bracket denote the arithmetic means \pm standard deviation $(n=3)$ of the indicated parameter and experimental condition. Different letters within each group of bars indicate values are significantly different at $p<0.05$ according to ANOVA.

Small and moderate inputs of OTC stimulated the enzyme activities, $15 \mathrm{mg} / \mathrm{kg}$ in the case of urease activity (Figure 2B) and $1 \mathrm{mg} / \mathrm{kg}$ OTC in the case of arylsulfatase, of soils regardless of the aboveground vegetative covers (Figure 2C). The high OCT input of $200 \mathrm{mg} / \mathrm{kg}$ treatment always resulted in significantly lower soil enzyme activities.

The enzymatic activities were normalized with respect to their respective activity maxima (Figure 3) and summed up by categories. The standardized mean soil enzyme activities of soils receiving 0,1 , and $15 \mathrm{mg} /$ $\mathrm{kg}$ OTC were significantly greater than that of the 200 $\mathrm{mg} / \mathrm{kg}$ OTC treatment for soils with no vegetation and the red amaranth aboveground cover but not the white clover aboveground cover. Again, the aboveground cover plants red amaranth and white clover yielded significantly different extent of harms on the soil enzymatic activities. (Figure 3).

\section{Discussion and Conclusions}

\subsection{Oxy-tetracycline on soil microbial biomass}

We used the phospholipids fatty acid profiles to indicate the structural changes of the microbial communities in the OTC affected soils and showed that the total bacterial and fungal biomass of soils receiving the low 
and moderate OTC inputs of less than $15 \mathrm{mg} / \mathrm{kg}$ were enhanced while those in soils receiving the extremely high OTC input of $200 \mathrm{mg} / \mathrm{kg}$ were significantly depressed with respect to outcomes of the no antibiotic experimental control. The aboveground vegetative covers, red amaranth and white clover, enhanced the total microbial biomass in soils receiving low and moderate OTC treatments and dampened the toxicity of antibiotics in soils receiving the high OTC treatment. It appeared that the manure in which the OTC was incorporated attenuated the potencies of antibiotics in the receiving soils. Only when the attenuation capacity was exceeded, did we observe the harms of antibiotics on the soil microbial biomass.

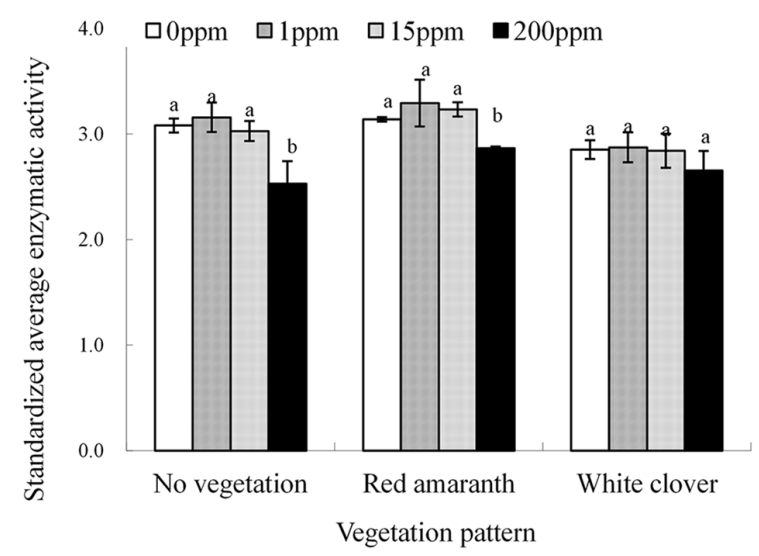

Figure 3. Aggregated enzymatic activity factor of dehydrogenase, urease, alkaline phosphatase, and arylsulfatase of soils seven weeks after receiving $0,1,15$ and $200 \mathrm{mg} / \mathrm{kg}$ of oxy-tetracycling under three types of vegetative covers. The soil enzyme activities were normalized by dividing the them with their respective maxima and then the aggregation was achieved by summing up the normalized values of each category.

\subsection{Oxy-tetracycline shifted soil microbial community structure}

When the antibiotic effect of OTC was suppressed, the manures stimulated the growth of both bacterial and fungal biomass in the soils with the bacteria outpaced the fungi and the Gram negative bacteria outpaced the Gram positive bacteria. When the toxicity of OTC was expressed, both the bacterial and fungal biomasses were reduced with respect to those of the no antibiotic experimental control. However, the ratios of bacterial/ fungal biomass shifted in favor of the bacteria especially the Gram-negative bacteria in the soils. The antibiotic toxicity of OTC although targeted the bacteria in the soils proportionally resulted in greater harmed against the soil fungi than the bacteria and the Gramnegative bacteria fared significantly better than the Gram-positive bacteria.

The stress factor reflected the overall conditions associated with soils' ability to support plant growth. The low stress factor represented healthy conditions for plant growth while high stress factor indicated the opposite. 
Apparently, the antibiotics did not present any significant harmful consequences for plant growth. The stress factors of the vegetated soils were consistently higher than those of the non-vegetated soils, reflected that red amaranth and white clover extracted nutrients to sustain their growth. The soil stress factors shifted higher as nutrients were withdrawn.

\subsection{Oxytetracycline lowered soil enzymatic activities}

The activities of dehydrogenase, urease, alkaline phosphatase, and arylsulfatase reflected the microbial well beings of the OTC treated soils. We showed that, when exposed to OTCs, not all soil enzymes behaved in the same manner. The activities of urease and alkaline phosphatase in OTC treated soils followed the same pattern as microbial biomass. The activities of dehydrogenase and arylsulfatase in the OTC affected soils decreased with the increases of OTC inputs. Collectively, the high OTC inputs lowered of soil enzymatic activities and the low and moderate OTC inputs did not have any adverse impact on the soil enzyme activities.

\subsection{Role of aboveground vegetative cover}

The aboveground vegetative covers played a minor role in dampened toxic effects of antibiotics.

\section{Acknowledgements}

We acknowledge the support of National Natural Science Foundation of China (\#41271503).

\section{References}

Boleas, S., Alonso, C., Pro, J., Fernández, C., Carbonell, G., Tarazona, J.V. 2005. Toxicity of the antimicrobial oxytetracycline to soil organisms in a multi-speciessoil system (MS.3) and influence of manure coaddition. J. Hazard. Mater. 122, 233-241.
Brandt, K.K., Berg, J., Thorsen, M.K., Holm, P.E., Jensen, J., Nybroe, O. 2010. Cu exposure under field conditions coselects for antibiotic resistance as determined by a novel cultivation-independent bacterial community tolerance assay. Environ. Sci. Technol. 44, 8724-8728.

Demoling, L.A., Baath, E., Greve, G., Wouterse, M., Schmitt, H. 2009. Effects of sulfamethoxazole on soil microbial communities after adding substrate. Soil Biol. Biochem. 41, 840-848.

Ding, C., He, J.Z. 2010. Effect of antibiotics in the environment on microbial populations. Appl. Microbiol. Biot. 87, 925-941.

Frostegard, A., Tunlid, A., Baath, E. 1993. Phospholipid fatty-acid composition, biomass, and activity of microbial communities from 2 soil types experimentally exposed to different heavy-metals. Appl. Environ. Microb. 59, 3605-3617.

Guan, S.Y. 1983. Soil enzymes and their determination methods. Chinese Agriculture Press, Beijing, China, 294-318p.

Halling-Sorensen, B., Nielsen, S.N., Lanzky, P. F., Ingerslev, F., Lutzhoft, H.C.H., Jorgensen, S.E. 1998. Occurrence, fate and effects of pharmaceutical substances in the environment - A review. Chemosphere. 36, 357-394.

Hammesfahr, U., Heuer, H., Manzke, B., Smalla, K., Thiele-Bruhn, S. 2008. Impact of the antibiotic sulfadiazine and pig manure on the microbial community structure in agricultural soils. Soil Biol. Biochem. 40, 1583-1591.

Jeong, J., Song, W., Cooper, W.J., Jung, J., Greaves, J. 2010. Degradation of tetracycline antibiotics: Mechanisms and kinetic studies for advanced oxidation/reduction processes. Chemosphere. 78, 533-540. 
Johnsen, A.R., Svenningsen, H., Henriksen, T., Prieme, A. 2011. Triclosan affects the microbial community in simulated sewage-drain-field soil and slows down xenobiotic degradation. Environ. Pollut. 159, 1599-1605.

Kong, W.D., Zhu, Y.G., Fu, B.J., Marschner, P., He, J.Z. 2006. The veterinary antibiotic oxytetracycline and $\mathrm{Cu}$ influence functional diversity of the soil microbial community. Environ. Pollut. 143, 129137.

Kotzerke, A., Hammesfahr, U., Kleineidam, K., Lamshoft, M., Thiele-Bruhn, S., Schloter, M., Wilke, B.M. 2011. Influence of difloxacincontaminated manure on microbial community structure and function in soils. Biol. Fert. Soils. 47, 177-186.

Liu, F., Ying, G.G., Tao, R., Zhao, J.L., Yang, J.F., Zhao, L.F. 2009. Effects of six selected antibiotics on plant growth and soil microbial and enzymatic activities. Environ. Pollut. 157, 1636-1642.

Liu, W.N., Pan, N., Chen, W.P., Jiao, W.T., Wang, M.E. 2012. Effect of veterinary oxytetracycline on functional diversity of soil microbial community. Plant Soil Environ. 58, 295-301.

Migliore, L., Godeas, F., De Filippis, S.P., Mantovi, P., Barchi, D., Testa, C., Rubattu, N., Brambilla, G. 2010. Hormetic effect(s) of tetracyclines as environmental contaminant on Zea mays. Environ. Pollut. 158, 129-134.

Sarmah, A.K., Meyer, M.T., Boxall, A.B.A. 2006. A global perspective on the use, sales, exposure pathways, occurrence, fate and effects of veterinary antibiotics (VAs) in the environment. Chemosphere. 65, 725-759.
Schmitt, H., Martinali, B., Van Beelen, P., Seinen, W. 2006. On the limits of toxicant-induced tolerance testing: Cotolerance and response variation of antibiotic effects. Environ. Toxicol. Chem. 25, 1961-1968.

Thiele-Bruhn, S., Beck, I.C. 2005. Effects of sulfonamide and tetracycline antibiotics on soil microbial activity and microbial biomass. Chemosphere. 59, 457-465.

Tolls, J. 2001. Sorption of veterinary pharmaceuticals in soils: A review. Environ. Sci. Technol. 35, $3397-$ 3406 .

Yang, Q., Zhang, J., Zhu, K., Zhang, H. 2009. Influence of oxytetracycline on the structure and activity of microbial community in wheat rhizosphere soil. J. Environ. Sci. 21, 954-959.

Zhou, Q.X., Bao, Y.Y., Wan, Y., Yu, Q.A., Xie, X.J. 2010. Effects of soil/solution ratios and cation types on adsorption and desorption of tetracycline in soils. Soil Sci. Soc. Am. J. 74, 1553-1561.

Zhou, Q.X., Xie, X.J., Lin, D.S., Guo, J.M., Bao, Y. Y. 2011. Toxic effect of tetracycline exposure on growth, antioxidative and genetic indices of wheat (Triticum aestivum L.). Environ. Sci. Pollut. R. 18, 566-575.

Zhu, Y.G., Wu, N., Qiao, M., Zhang, B., Cheng, W. D. 2010. Abundance and diversity of tetracycline resistance genes in soils adjacent to representative swine feedlots in China. Environ. Sci. Technol. 44, 6933-6939. 